\title{
Sex-Linked Differences in the Mortality in Ren-2 Transgenic Hypertensive Rats With Aorto-Caval Fistula: Effects of Treatment With Angiotensin Converting Enzyme Alone and Combined With Inhibitor of Soluble Epoxide Hydrolase
}

\author{
P. KALA ${ }^{1}$, L. ČERVENKA ${ }^{2,3}$, P. ŠKAROUPKOVÁ ${ }^{2}$, M. TÁBORSKÝ ${ }^{4}$, \\ E. KOMPANOWSKA-JEZIERSKA ${ }^{5}$, J. SADOWSKI
}

${ }^{1}$ Department of Cardiology, University Hospital Motol and Second Faculty of Medicine, Charles University, Prague, Czech Republic, ${ }^{2}$ Center for Experimental Medicine, Institute for Clinical and Experimental Medicine, Prague, Czech Republic, ${ }^{3}$ Department of Pathophysiology, Second Faculty of Medicine, Charles University, Prague, Czech Republic, ${ }^{4}$ Department of Internal Medicine I, Cardiology, University Hospital Olomouc and Palacký University, Olomouc Czech Republic, ${ }^{5}$ Department of Renal and Body Fluid Physiology, Mossakowski Medical Research Centre, Polish Academy of Science, Warsaw, Poland

Received November 27, 2018

Accepted May 3, 2019

Epub Ahead of Print June 6, 2019

\section{Summary}

We found recently that in Ren-2 transgenic hypertensive rats (TGR) addition of soluble epoxide hydrolase inhibitor (sEHi) to treatment with angiotensin-converting enzyme inhibitor (ACEi), surprisingly, increased the mortality due to heart failure (HF) induced by creation of the aorto-caval fistula (ACF). Since TGR exhibit sex-related differences in mortality, we examined here if such differentiation exists also in the response to the treatment with ACEi (trandolapril), alone or combined with sEHi [Cis-4-[4(3-adamantan-1-yl-ureido)cyclohexyloxy]benzoic acid, (c-AUCB)]. ACEi improved survival in males to $74 \%$ (vs. $0 \%$ ) and in females to $65 \%$ (vs. $32 \%$ ). ACEi and sEHi combined also improved the survival in male ACF TGR, however, it was significantly less (38\%) than after ACEi alone. In contrast, in females the combined treatment significantly improved the final survival rate $(84 \%)$. There were no significant sex-linked differences in survival rate in untreated or treated normotensive Hannover Sprague-Dawley rats. In conclusion, in HF patients with co-existing hypertension and RAS hyperactivity, the sex may co-determine the rate of HF progression, and can influence the effectiveness of the therapeutic measures applied. Therefore, in the relevant pre-clinical studies the sex-linked differences should be seriously considered. Our data indicate that TGR might be an optimal model for such studies.

\section{Key words}

Heart failure - Sex differences in pathophysiology • Aorto-caval fistula - Hypertension - Renin-angiotensin system - Soluble epoxide hydrolase inhibitor • Angiotensin-converting enzyme inhibitor

\section{Corresponding author}

L. Červenka, Center for Experimental Medicine, Institute for Clinical and Experimental Medicine, 1958/9 Vídeňská, CZ-140 00 Prague 4, Czech Republic. E-mail: luce@medicon.cz

\section{Introduction}

Congestive heart failure (HF) affects $4 \%$ of the adult population in Europe (Maggioni 2015) and without a significant progress in the prevention and/or treatment, a $50 \%$ yearly increase in the HF patient population is expected. The current survival rate of HF patients is low: almost $50 \%$ die within 5 years from the diagnosis (Braunwald 2015, Ponikowski et al. 2016, Yancy et al. 2017). Increased activity of the renin-angiotensin system (RAS) plays an important role in the pathophysiology of $\mathrm{HF}$ and its blockade by angiotensin-converting enzyme inhibitor (ACEi) is a golden standard therapy. However, 
in the advanced $\mathrm{HF}$ its effectiveness is limited (CONSENSUS Trial Study Group 1987, Ferrario and Mullick 2017, Kassi et al. 2018, SOLVD Investigators 1992, Yancy et al. 2017). It has also been shown that in the HF induced by volume overload, RAS inhibition did not attenuate eccentric remodeling of the left ventricle or improve its systolic function (Červenka et al. 2015a, Plante et al. 2009, Ryan et al. 2007).

In search for new therapeutic measures considerable attention focused on the role of epoxyeicosatrienoic acids (EETs), cytochrome P-450 (CYP)-dependent epoxygenase pathway metabolites of arachidonic acid (AA); increased EETs levels were reported to exert antihypertensive and organ-protective actions (Elmarakby 2012, Imig 2018, Kujal et al. 2014). This was so even though therapeutic potential of EETs is limited by their rapid break-down to biologically inactive dihydroxyeicosatrienoic acids (DHETEs) by soluble epoxide hydrolase (sEH). Nevertheless, blocking sEH and increasing tissue EETs bioavailability had, indeed, antihypertensive and cardio- and renoprotective effects (Imig 2018) and, in spite of some controversial results (Červenka et al. 2015a, Červenka et al. 2015b, Imig 2018, Kala et al. 2018), the blockade could represent a valuable addition to the pharmacological blockade of the RAS.

Notably, the risk of HF in women is generally underestimated and men are thought to be at greater risk for heart diseases (including HF) (Cook JL et al. 2015, Eisenberg et al. 2018, Westerman and Wenger 2016). This notion was more recently challenged: in the cohort of HF patients with reduced ejection fraction women showed a greater mortality (Petrie et al. 1999, Westerman and Wenger 2016) and a worse quality of life than men (Hsich and Pina 2009, Eisenberg et al. 2018, Lewis et al. 2007). Moreover, while the incidence and prevalence of $\mathrm{HF}$ is greater in men, the absolute number of patients with HF in either sex is similar, due to higher longevity in women (Eisenberg et al. 2018, Westerman and Wenger 2016). Remarkably, $59.5 \%$ of all annual deaths of HF patients are women (Bolijn et al. 2017, Eisenberg et al. 2018, Westerman and Wenger 2016). Furthermore, the risk of the $\mathrm{HF}$ following myocardial infarction is higher in women (Lam et al. 2015). All this data point to the need of the studies of the biological mechanisms underlying the sex-related differences in HF, and of the responses to new pharmacological measures (Bolijn et al. 2017, Eisenberg et al. 2018, Regitz-Zagrosek and Karagigas 2017, Westerman and Wenger 2016).

The rat model in which HF is induced by volume overload induced by creation of the aorto-caval fistula (ACF) (Hatt et al. 1980) has many features similar to the untreated human HF (Abassi et al. 2011, Brower et al. 1996, Cohen-Segev et al. 2014, Červenka et al. 2015a, Melenovsky et al. 2012, Melenovsky et al. 2018), and is recommended by American Heart Association for testing therapeutic strategies for CHF (Houser et al. 2012). Unfortunately, most researchers employ male animals only, which generates incomplete or misleading data (Arnold et al. 2017, Blenck et al. 2016, Miller et al. 2017, Regitz-Zagrosek and Karagigas 2017). Notably, even though sex differences in volume overload model of CHF were only rarely studied, some sex-related differences in survival rate and cardiac remodeling were found (Červenka et al. 2016, Gardner et al. 2005, Dent et al. 2010, Lu et al. 2012). It will be noticed that the hypertensive rat transgenic for the mouse Ren-2 renin gene [TGR; strain name TGR(mRen2)27] presents a unique model which combines two critical determinants of the progression of HF: hypertension and RAS hyperactivity (Kopkan et al. 2005, Lee et al. 1996, Mullins et al. 1990). We found that TGR exhibit remarkable sex-related difference in HF-related mortality (Červenka et al. 2016), and also that that male ACF TGR displayed tissue deficiency of EETs. Furthermore, increasing intrarenal EETs levels by pharmacological blockade of SEH attenuated the progression of HF in male ACF TGR (Červenka et al. 2015a). However, we did not examine if this effect occurs also in female ACF TGR. Moreover, we found recently that in male ACF TGR addition of sEH inhibitor (sEHi) to the standard treatment with ACEi did not further enhance the protection against ACF-induced HF but, surprisingly, lowered the survival rate (Kala et al. 2018).

Since the studies of the possible role of CYPdependent epoxygenase metabolites of $\mathrm{AA}$ in the pathophysiology of ACF-induced HF were performed in male animals only, we examined here the possible sex dependence of the response to sEH inhibition using the TGR with ACF-induced HF, probably the model most suitable for the purpose. The aim was to establish if sex-related differences, if present, are demonstrable with standard treatment with ACEi alone and with the combined treatment with ACEi and sEHi.

\section{Methods}

Ethical approval, animals, CHF model, and pharmacological therapeutic regimes

The studies were performed in accordance with 
guidelines and practices established by the Animal Care and Use Committee of the Institute for Clinical and Experimental Medicine, Prague, which accord with the European Convention on Animal Protection and Guidelines on Research Animal Use. All animals used in the present study were bred at the Center of Experimental Medicine of this Institute, which is accredited by the Czech Association for Accreditation of Laboratory Animal Care. Heterozygous TGR were generated by breeding male homozygous TGR with female homozygous transgene-negative normotensive Hannover Sprague-Dawley (HanSD) rats and age-matched HanSD rats served as controls. The animals were kept on a 12-hour/12-hour light/dark cycle. Throughout the experiments rats were fed a normal salt, normal protein diet $(0.45 \% \mathrm{NaCl}, 19-21 \%$ protein $)$ manufactured by SEMED (Prague, Czech Republic) and had free access to tap water.

Male and female TGR and HanSD rats, at the initial age of 8 weeks, derived from several litters, were randomly assigned to experimental groups to make sure that the animals from a single litter did not prevail in any group. In order to obtain reliable data regarding the effects of two treatment regimens and possible sex-linked differences on the survival rate, high initial $n$ values were used (not so for sham-operated animals) to enable valid comparison of the long-term survival rate. To define such required initial $n$ values, statistical power analysis by the method developed by Cohen (2013) was applied; specifically, a program package that includes the desired test was used (http://www.gpower.hhu.de).

Rats were anesthetized (tiletamine + zolazepam, Virbac SA, Carros Cedex, France, $8 \mathrm{mg} / \mathrm{kg}$; and xylasine, Spofa, Czech Republic, $4 \mathrm{mg} / \mathrm{kg}$ intramuscularly) and HF was induced by volume overload caused by ACF created using needle technique as employed and validated by many investigators, including our own group (Abassi et al. 2011, Brower et al. 2015, Cohen-Segev et al. 2014, Červenka et al. 2015a, Červenka et al. 2015b, Červenka et al. 2016, Hatt et al. 1980, Kala et al. 2018, Melenovský et al. 2012, Melenovský et al. 2018, Sporková et al. 2017). Briefly, after exposure of the abdominal aorta and inferior vena cava between the renal arteries and iliac bifurcation, the aorta was temporarily occluded at this segment for about 40 seconds. An 18-gauge needle (diameter $1.2 \mathrm{~mm}$ ) was inserted into the abdominal aorta and advanced across its wall into the inferior vena cava to create ACF. Thereafter the needle was withdrawn and the puncture site was sealed with cyanoacrylate tissue glue. Successful creation of ACF was confirmed by inspection of pulsatile flow of oxygenated blood from the abdominal aorta into the vena cava. Sham-operated rats underwent an identical procedure but without creating ACF. To inhibit sEH, cis4-[4-(3-adamantan-1-yl-ureido) cyclohexyloxy]benzoic acid ( $c$-AUCB) - an sEHi was used, which was prepared freshly and given in drinking water at $3 \mathrm{mg} / \mathrm{l}$. The appropriate amount of $c$-AUCB was dissolved under gentle warming in polyethyleneglycol and added under rapid stirring to warm drinking water, to obtain $0.1 \%$ aqueous solution of polyethylenglycol. The dose of $c$-AUCB was selected based on our recent studies where it elicited substantial increases in tissue concentration of EETs without altering RAS activity (Červenka et al. 2015a, Červenka et al. 2015b, Kala et al. 2018, Sporková et al. 2014). Trandolapril (6 mg/l in drinking water; Gopten; Abbot, Prague, Czech Republic), was used as ACEi, because in our previous studies this dose provided maximal blockade of RAS and was well tolerated by rats with ACF-induced HF and by sham-operated animals (Červenka et al. 2015a, Červenka et al. 2015b, Kala et al. 2018).

\section{Detailed experimental design}

Effects of treatment with ACEi alone or combined with sEHi on the survival rate

The rats underwent sham-operation or ACF creation as described above on the week labeled 1, and were left without treatment during 1 week. At this time point (week 0 ) the rats were divided into the following experimental groups:

1. Sham-operated male HanSD rats + placebo (initial $n=9$ )

2. ACF male HanSD rats + placebo (initial $n=26$ )

3. ACF male HanSD rats + ACEi (initial $n=27$ )

4. ACF male HanSD rats $+\mathrm{ACEi}+\mathrm{sEHi}$ (initial $\mathrm{n}=26$ )

5. Sham-operated female HanSD rats + placebo (initial $n=9$ )

6. ACF female HanSD rats + placebo (initial $\mathrm{n}=27$ )

7. $\mathrm{ACF}$ female HanSD rats $+\mathrm{ACEi}$ (initial $\mathrm{n}=27$ )

8. ACF female HanSD rats $+\mathrm{ACEi}+\mathrm{sEHi}$ (initial $\mathrm{n}=26$ )

9. Sham-operated male TGR + placebo (initial $\mathrm{n}=9$ )

10. ACF male $\mathrm{TGR}+$ placebo (initial $\mathrm{n}=33$ )

11. ACF male TGR + ACEi (initial $n=34$ )

12. $\mathrm{ACF}$ male $\mathrm{TGR}+\mathrm{ACEi}+\mathrm{sEHi}($ initial $\mathrm{n}=37$ ) 
13. Sham-operated female TGR + placebo (initial $\mathrm{n}=10$ )

14. $\mathrm{ACF}$ female $\mathrm{TGR}+$ placebo (initial $\mathrm{n}=37$ )

15. ACF female TGR + ACEi (initial $n=34$ )

16. ACF female TGR + ACEi + sEHi (initial $n=36$ )

The follow-up period was the same as in our previous studies i.e. 50 weeks (Červenka et al. 2015a, Červenka et al. 2015b, Kala et al. 2018).

\section{Statistical analysis}

Statistical analysis of the data was performed using Graph-Pad Prism software (Graph Pad Software, San Diego, California, USA). Comparison of survival curves was performed by log-rank (Mantel-Cox) test followed by Gehan-Breslow-Wilcoxon test.

\section{Results}

All sham-operated male and female HanSD rats survived until the end of experiment. As shown in Figs $1 \mathrm{~A}$ and $1 \mathrm{~B}$, male and female untreated ACF HanSD rats clearly began to die by week 15 (i.e. 16 weeks after

\section{$A$}

ACF HanSD male

ACF HanSD + ACEi male

$\triangle A C F$ HanSD + ACEi + sEHi male

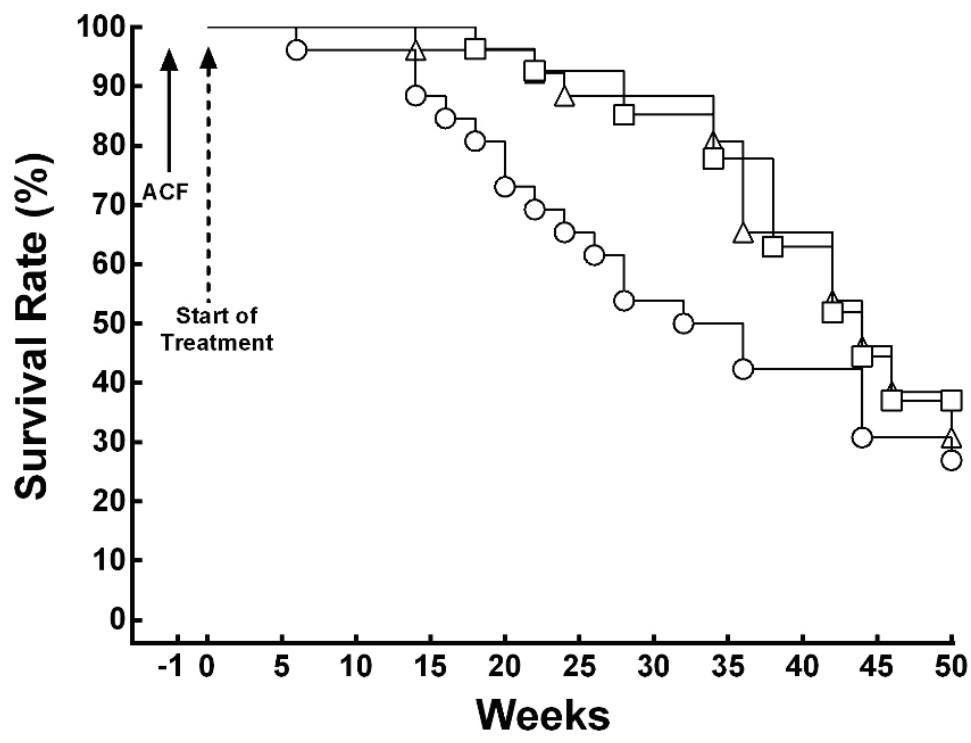

Fig. 1. Survival rates in male (A) and female (B) untreated transgene-negative Hannover Sprague-Dawley (HanSD) rats with aorto-caval fistula (ACF HanSD), in ACF HanSD treated with angiotensinconverting enzyme inhibitor (ACF HanSD + ACEi) and in ACF HanSD treated with the combination of angiotensinconverting enzyme inhibitor and soluble epoxide hydrolase inhibitor (ACF HanSD + ACEi $+\mathrm{sEHi}$ ). The comparison of the survival rates curves was performed by log-rank Mantel-Cox test followed by Gehan-Breslow-Wilcoxon test.

B

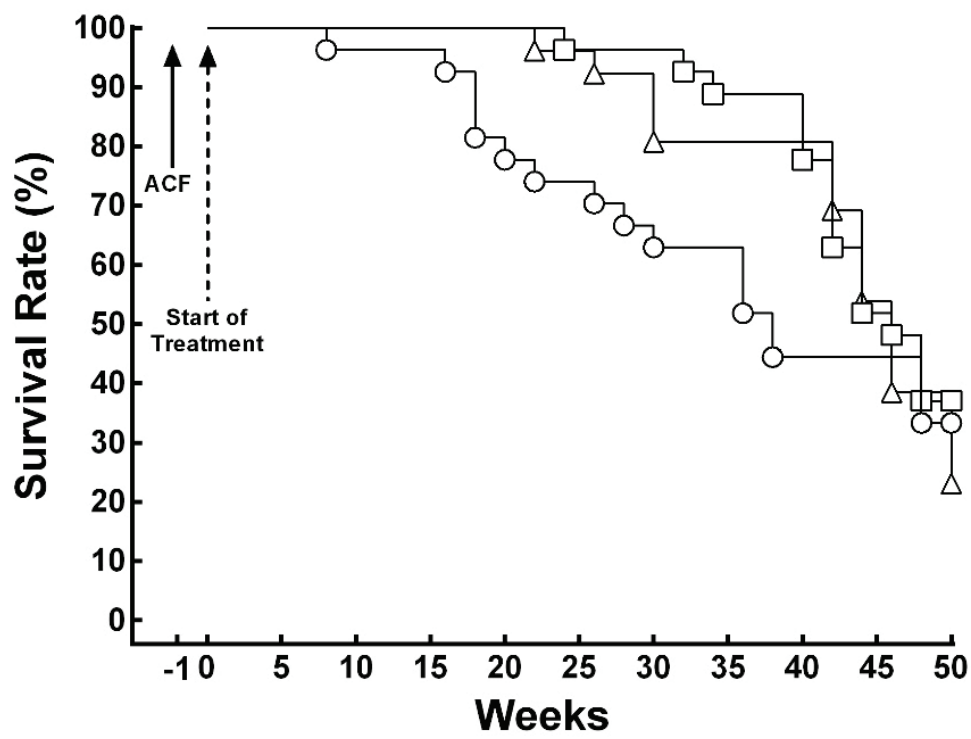


induction of ACF) and the course of survival and the final survival was almost identical for either sex. In male rats 7 of 26 animals (i.e. $27 \%$ ) and in female rats 8 of 27 animals (i.e. $30 \%$ ) survived, respectively. The treatment with ACEi improved the course of survival rate in male and female ACF HanSD rats until the week 35, thereafter both male and female animals began to die, and the final survival rate was similar as observed in untreated male and female ACF HanSD rats. With the combined ACEi and sEHi treatment, the course of survival rate in male and female ACF HanSD rats was almost identical as in those treated with ACEi alone.

Quite similarly, HanSD rats and all shamoperated male and female TGR survived until the end of experiment.

\section{A}

ACF TGR male

ACF TGR + ACEi male

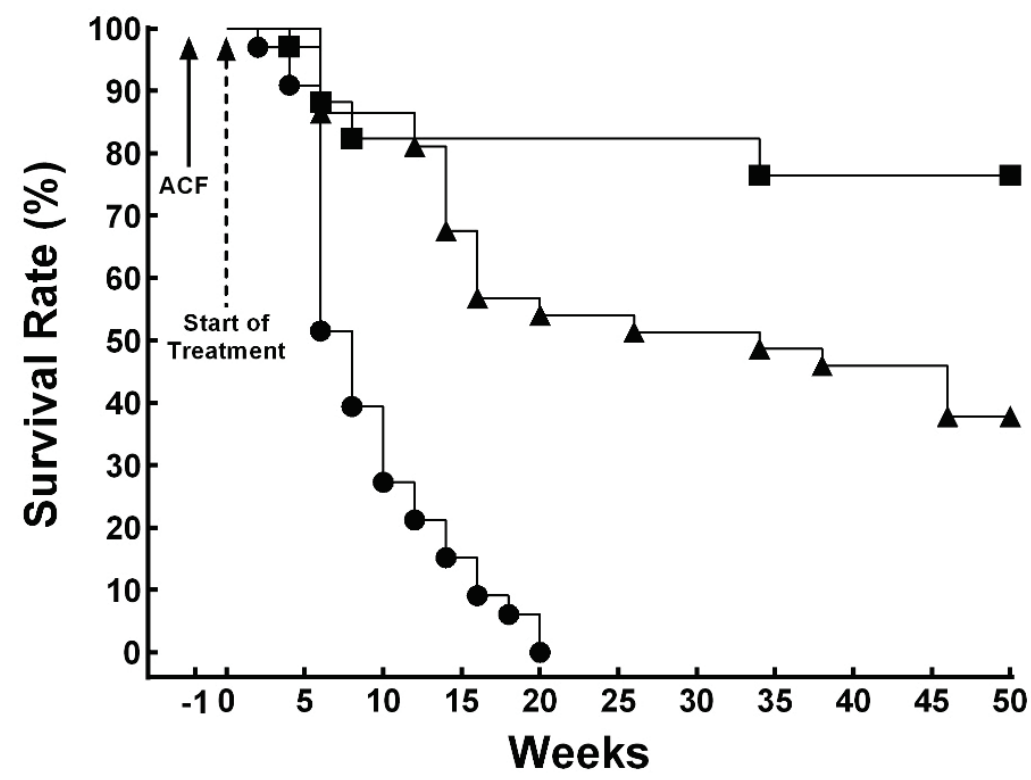

B

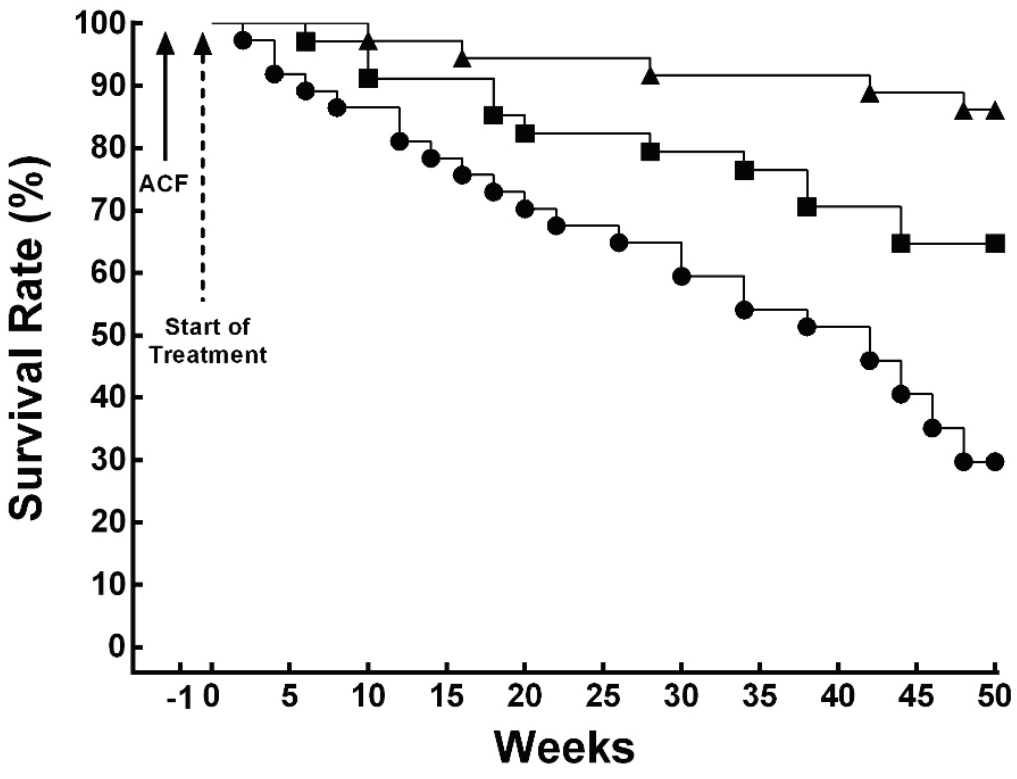

Fig. 2. Survival rates in male (A) and female (B) untreated heterozygous Ren-2 transgenic rats (TGR) with aorto-caval fistula, (ACF TGR), in ACF TGR treated with angiotensinconverting enzyme inhibitor (ACF TGR + ACEi) and in ACF TGR treated with the combination of angiotensin converting enzyme inhibitor and soluble epoxide hydrolase inhibitor (ACF TGR + ACEi + $s E H i)$. The comparison of the survival rates curves was performed by log-rank MantelCox test followed by GehanBreslow-Wilcoxon test.

\section{ACF TGR + ACEi female \\ ACF TGR female \\ $\star \mathrm{ACF} T \mathrm{TR}+\mathrm{ACEi}+\mathrm{sEHi}$ female}


As shown in Figure 2A, untreated male ACF TGR began to die by week 2 (i.e. 3 weeks after induction of ACF) and all animals died by week 20. In contrast, untreated female ACF TGR began to die by week 4 (i.e. 5 weeks after induction of ACF) and the final survival rate was $32 \%$. The treatment with ACEi substantially improved survival rate in male as well as in female ACF TGR, and the final rate value was comparable, at $74 \%$ and $65 \%$, respectively (Figs 2A, B). As shown in Figure 2A, the combined treatment with ACEi and sEHi also improved the survival in male ACF TGR as compared with untreated ACF TGR, however, the course and the final survival rate (only $38 \%$ ) was significantly worse than observed in male ACF TGR treated with ACEi alone. In contrast, the combined treatment with ACEi and sEHi in female ACF TGR significantly improved the course and the final survival rate (to $84 \%$ ) as compared with female ACF TGR treated with ACEi alone (Fig. 2B).

\section{Discussion}

We found that there was no significant difference in the survival rate between untreated male and female ACF HanSD rats. Moreover, the treatment with ACEi alone and combined treatment with ACEi and sEHi had almost identical effects on the course of survival rate in the male and female rats. These findings are in accordance with our report (Červenka et al. 2016) that intact normotensive HanSD rats do not show any sex-linked differences in the course of ACF-induced HF. The new important finding is that, in addition, these animals do not show any sex-related difference in response to the treatment with ACEi alone or combined treatment with ACEi and sEHi. Moreover, we found that while ACEi effectively improved the survival rate in the early phase after creation of ACF, it lost its effectiveness in the advanced phase (around week +35 ); thereafter both male and female ACF HanSD rats clearly began to die, and the final survival rate was almost identical with that observed in their untreated counterparts. These findings further support the notion that new pharmacological measures are required for the treatment of $\mathrm{HF}$ in its advanced phase (Braunwald 2015, Kassi et al. 2018, SOLVD Investigators 1992, Yancy et al. 2017). Furthermore, the finding that the addition of sEHi treatment did not enhance protective actions against HF-related mortality in male and female ACF HanSD rats obtained with ACEi alone is in accordance with our recent study. It showed that in male ACF HanSD rats the treatment with sEHi alone did not improve the course of $\mathrm{HF}$, despite the fact that it restored intrarenal and myocardial EETs to levels observed in sham-operated HanSD rats (Červenka et al. 2015b).

Taken together, the findings show that HanSD rats do not exhibit important sex-linked differences in ACF-induced HF-related mortality. Nor do they show any significant sex-related differences in the response to pharmacological treatment with ACEi and sEHi. Therefore, the results indicate that in HanSD rats, and probably also in other normotensive strains, studies evaluating the pathophysiology of ACF-induced HF and new pharmacological strategies for its treatment can be successfully conducted in animals of either sex. Based on our present and previous results (Červenka et al. 2015b) we believe that increasing tissue EETs concentrations by pharmacological blockade of sEH does not seem to be a promising approach to attenuate the progression of $\mathrm{HF}$ in normotensive animals, at least in the model of ACF-induced HF.

The studies of the course of ACF-induced HF in male as compared to female TGR disclosed a different situation and patterns. We found that, first, the male ACF TGR exhibited markedly lower survival rate than observed in female ACF TGR. Second, the treatment with ACEi alone had protective effects on the course of HF-dependent mortality in male and female rats. Third, our results show that the combined ACEi and sEHi treatment had different effects in male versus female ACF TGR: it increased the HF-related mortality in male and decreased it in female rats, when the results are compared with ACEi treatment alone. Evidently, hypertensive TGR show important sex-linked difference in ACF-induced HF mortality which was significantly higher in the males. In addition, ACF TGR show an important sex-related difference in the response to the combined ACEi and sEHi treatment: it worsened the survival rate in male and improved it in female rats, in comparison with ACEi treatment alone.

In view of this knowledge, we conclude that in TGR, a strain with two critically important detrimental factors promoting progression of HF (hypertension and inappropriately increased RAS activity), the studies exploring the pathophysiology of HF should be performed in rats of both sexes; this is particularly important in the case of studies evaluating new measures for HF treatment.

It was puzzling to find that addition of sEHi to 
ACEi treatment improved the effect on the HF-dependent mortality in the female but worsened it in male TGR: no satisfactory explanation can here be offered. The rationale of the combined treatment was that when two different vasoactive systems are affected, additive protective effects could be expected. There is evidence that in TGR the ACF model of HF is characterized by marked activation of the RAS and by profound deficiency of tissue EETs. Both pharmacological blockade of the RAS alone (ACEi treatment) and increasing tissue availability of EETs (sEHi treatment) (using the same drugs and doses as employed in the present study) clearly revealed beneficial effects on the HF-related mortality in ACF TGR (Červenka et al. 2015a). We cannot provide any clear explanation for such discrepant sex-related divergent effects of the combined ACEi and sEHi treatment on the HF-dependent mortality. However, several potentially relevant issues whose consideration might provide some insight in the nature of this important difference should here be mentioned.

First, our recent study (Červenka et al. 2016) using the classical experimental approach to explore sex-linked differences, i.e. comparing intact animals with animals after gonadectomy (Ostadal et al. 2009, RegitzZagrosek and Karagigas 2017), indicated that the harmful influence of testosterone rather than protective effects of estrogens is responsible for the sex-linked differences in ACF HF-related mortality in TGR (Červenka et al. 2016). The view that testosterone could be involved in the relatively poorer prognosis in male ACF TGR is also supported by findings showing that testosterone plays an important role in mediating hypertension-induced endorgan damage in male TGR (Vaněčková et al. 2011). Therefore, the tentative conclusion might be that in male TGR testosterone-mediated alterations could be crucial for the increasing ACF-induced HF-related mortality in response to combined treatment with ACEi and sEHi (compared to ACEi treatment alone). To assess this hypothesis, comprehensive long term studies are needed in animals after gonadectomy, after gonadectomy with substitution of appropriate sex hormones, and gonadectomy with administration of steroid hormones of the opposite sex, as well as studies of post-menopausal females, without and with hormonal supplementation. Such animal groups should be exposed to the same protocol as used in the present study. Obviously, such studies are difficult to perform and interpret; nevertheless, they are needed to provide the basis for the exploration of the mechanism(s) responsible for the sex-linked differences in ACF TGR.

Second, elevation of angiotensin II (ANG II) levels is known to increase tissue protein expression of sEH (Ai et al. 2007). Therefore, one could suspect that sex-related differences in the RAS activity, and, consequently, in tissue $\mathrm{sEH}$ expression/activity, and finally in the tissue EETs bioavailability, might be responsible for the sex-related difference in the response to the combined treatment with ACEi and sEHi. However, in our previous studies no significant difference was found in plasma and kidney ANG II between male and female TGR (Husková et al. 2007, Vaněčková et al. 2011). Moreover, the well-known marked sex-related difference in the course of hypertension development in TGR (Lee et al. 1996, Vaněčková et al. 2011) cannot be simply ascribed to different RAS activity. In addition, unpublished data from preliminary experiments to our previous studies (Červenka et al. 2015a, Červenka et al. 2015b, Červenka et al. 2016) showed no important sex-dependent differences in heart and kidney tissue EETs bioavailability, in sEH protein expression or in protein expression of CYP2C23 and CYP2J3, the crucial enzymes of the relevant pathways; this was so both in ACF TGR and ACF HanSD rats. This indicates that in normotensive and hypertensive animals of either sex the renal and cardiac generation of EETs is normal. Evidently, the deficiency of EETs in ACF TGR and ACF HanSD rats is the result of its increased conversion to DHETEs, as indicated by increased tissue sEH protein expression (Červenka et al. 2015a, Červenka et al. 2015b, Červenka et al. 2016, and unpublished data from preliminary experiments).

Taken together, these data suggest that sex-related differences in tissue sEH expression/activity are unlikely to be the mechanism responsible for the different response to combined treatment with ACEi and sEHi in ACF TGR. Perhaps one should consider here the recent evidence (Hrdlička et al. 2019) that in the model of postischemic HF the treatment with sEHi attenuated the progression of HF in normotensive HanSD rats but not in hypertensive TGR. This is opposite to our findings in the ACF-induced model of HF (Červenka et al. 2015a, Červenka et al. 2015b) which suggest that the experimental model can be per se an important determinant of the ultimate effect of EETs-based therapy on the cardiovascular disease. Nevertheless, sex-related differences in the role of CYP-dependent eicosanoids in the regulation of cardiovascular function require further 
exploration (Jamieson et al. 2017). For instance, it has been shown that the deletion of the gene encoding $\mathrm{sEH}$ (Ephx2 -/- mice) is an important determinant of the arteriolar responsiveness to shear stress in males but not in females (Qin et al. 2015). On the other hand, the same group found that female Ephx2 -/- mice had greater cardiac contractility than their male counterparts, indicating that $\mathrm{sEH}$ is important in the regulation of cardiac function both in females and in males (Qin et al. 2016). Evidently, the sex-specificity of the cardiovascular responses to CYP-dependent eicosanoids depends also on the actual parameter that is evaluated.

The third issue to consider here is that blood pressure (BP) is lower in female than in male TGR, owing to a decrease observed in the former after the 5th month of age (Lee et al. 1996, Vaněčková et al. 2011). It is known that a J-shaped relationship exists between systolic BP and clinical outcomes (all-cause and cardiovascular mortality etc.) in HF patients (PinhoGomes and Rahimi 2019). Therefore, one could assume that the combination of ACF creation with combined treatment with ACEi and sEHi could result in additive BP-lowering actions, to result in increased mortality dependent on the shift to the left side of the J-shaped curve. However, our original study in male TGR showed that after an initial drop in BP after ACF creation, within 56 hours BP returned to values observed in shamoperated HanSD rats (Červenka et al. 2015a) and in our recent study (Kala et al. 2018) we found that the BP values in male ACF TGR treated with the combined treatment did not significantly differ from those measured in rats receiving $\mathrm{ACEi}$ alone. Moreover, given the lower BP in female TGR, one would expect that a negative effect of inappropriate BP-lowering on the survival rate in ACF TGR exposed to the combined ACEi and sEHi treatment should be greater in the females. Therefore, it seems unlikely that exaggerated BP-lowering effect of the combined treatment is responsible for the increased HF-related mortality in male as compared with female ACF TGR. Nevertheless, to finally solve this question, comprehensive long-term studies are needed involving radiotelemetric BP measurements in conscious animals. Unfortunately, this is a challenge, considering, for instance, the insufficient durability of telemetric probes.

The fourth issue to be considered is the possible role of CYP-450-dependent $\omega$-hydroxylase pathway of AA metabolism. Its increased activity and increased production of 20-hydroxyeicosatrienoic acid (20-HETE) is thought to affect adversely the renal and myocardial tissue and promote the progression of HF (Jamieson et al. 2017, Rocic and Schwartzman 2018). Since in male spontaneously hypertensive rats (SHR) the renal 20-HETE production is greater than in their normotensive counterparts (Ishizuka et al. 2004), and 20-HETE formation is androgen-dependent (Jamieson et al. 2017, Rocic and Schwartzman 2018, Roman and Fan 2018), one could assume that increased tissue 20-HETE could be responsible for the for the sex-related difference in the response to combined ACEi and sEHi treatment. Admittedly, our previous studies (Červenka et al. 2015a, Červenka et al. 2015b) did not confirm the involvement of the CYP-450-dependent $\omega$-hydroxylase pathway in the progression of HF in male ACF TGR and ACF HanSD rats. However, possible role of this pathway has not been evaluated in female rats so that its role in sex-specific responses to the combined treatment with ACEi and sEHi cannot be excluded.

The fifth issue to consider is the emerging role of alternative pathways within the RAS. In addition to the main functional axis consisting of angiotensin I (ANG I), angiotensin-converting enzyme (ACE), ANG II, and ANG II type $1\left(\mathrm{AT}_{1}\right)$ receptors. So far, the existing strategy in cardio-renal diseases focused on blocking $\mathrm{ACE}$ or $\mathrm{AT}_{1}$ receptors (Hošková et al. 2017, Kobori et al. 2007, Kopkan and Červenka 2009). This approach may have to be modified due to the discovery of angiotensin1-7 (ANG 1-7), generated from ANG II through a newly identified ACE type enzyme (ACE2), or by conversion of ANG I through an endopeptidase neprilysin. ANG 1-7 activates unique G-protein-coupled Mas receptors to induce important biological actions (Santos et al. 2018, South et al. 2019). It is now thought that the ACE2/ANG 1-7/Mas receptor axis counteracts detrimental actions of

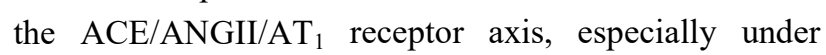
conditions of general RAS activation: indeed, some beneficial effects of $\mathrm{ACEi}$ or $\mathrm{AT}_{1}$ receptor blockers could be attributed to the activity shift in the favor of the ACE2/ANG 1-7/Mas receptor axis (Santos et al. 2018, South et al. 2019). Interestingly, renal tissue content of ANG 1-7 (but not ANG II) is significantly higher in female than in male SHR (Pendergrass et al. 2006, Sullivan et al. 2010) and important sex-related differences exist in the regulation and/or activity of the ACE2/ANG 1-7/Mas receptor axis (Santos et al. 2018, South et al. 2019). Therefore, different degree of activation of the ACE2/ANG 1-7/Mas receptor axis in males versus females might contribute to the sex-related difference in the response to combined treatment with 
ACEi and sEHi in ACF TGR. On the other hand, our recent study has questioned the importance of the ACE2/ANG 1-7/Mas receptor axis in the pathophysiology of ANG II-dependent hypertension (Husková et al. 2016) It is apparent that further studies are required to address this issue.

Apart from the above discussed issues, our present study reveals one important limitation, which is lack of assessment of possible sex-linked differences in the cardiac remodeling and cardiac function. Therefore, future studies evaluating the potential sex-related differences in cardiac function employing echocardiography and pressure-volume analysis are needed.

In conclusion, we found that the treatment with ACEi alone displayed similar beneficial effects on the course of ACF-induced HF in male and female TGR. In contrast, the combined treatment with ACEi and sEHi showed sex-dependent effects: it, increased the HF-related mortality (relative to ACEi treatment alone) in male and reduced it in female rats. In general, the study strongly suggests that in HF individuals in whom hypertension and increased RAS activity run in parallel, the patients' sex is a co-determinant of the rate of progression of HF. In particular, it can influence the effectiveness of the therapeutic measures applied to slow it down. Therefore, in pre-clinical studies the sex-linked differences should be seriously considered. Our data indicate that TGR might be an optimal model for such studies.

\section{Conflict of Interest}

There is no conflict of interest.

\section{Acknowledgements}

This study was primarily supported by the Ministry of Health of the Czech Republic grant no. 17-28220A awarded to M. Táborský. All rights reserved. Peter Kala is Ph.D. student who is supported by the Grant Agency of Charles University, project number 32218.

\section{References}

ABASSI Z, GOLTSMNA I, KARRAM T, WINAVER J, HOFFMAN A: Aortocaval fistula in rat: a unique model of volume-overload congestive heart failure and cardiac hypertrophy. J Biomed Biotechnol 729497, http://dx.doi.org/10.1155/2011/729497, 2011.

AI D, FU Y, GUO D, TANAKA H, WANG N, TANG C, HAMMOCK BD, SHYY JY, ZHU Y: Angiotensin II up-regulates soluble epoxide hydrolase in vascular endothelium in vitro and in vivo. Proc Natl Acad Sci USA 104: 9018-9023, 2007.

ARNOLD AP, CASSIS LA, EHBALI M, REUE K, SANDBERG K: Sex hormones and sex chromosomes cause sex differences in the development of cardiovascular diseases. Arterioscler Tromb Vasc Biol 37: 746-756, 2017.

BLENCK CL, HARVEY PA, RECKELHOFF JF, LEINWAND LA: The importance of biological sex and estrogen in rodent models of cardiovascular health and disease. Circ Res 118: 1294-1312, 2016.

BOLIJN R, ONLAND-MORET C, ASSELBERGS FW, VAN DER SCHOUW YT: Reproductive factors in relation to heart failure in women: a systematic review. Maturitas 106: 57-72, 2017.

BRAUNWALD E: The war against heart failure. Lancet 385: 812-824, 2015.

BROWER GL, HENEGAR JR, JANICKI JS: Temporal evaluation of left ventricular remodeling and function in rats with chronic volume overload. Am J Physiol 40: H2071-H2078, 1996.

COHEN J: Some issue in power analysis. In: Statistical Power Analysis for the Behavioral Sciences. COHEN J (Ed.). Routlede $2^{\text {nd }}$ edition, 2013, pp. 531-542.

COHEN-SEGEV R, FRANCIS B, ABU-SALEH N, AWAD H, LAZAROVICH A, KABALA A, ARONSON D, ABASSI Z: Cardiac and renal distribution of ACE and ACE-2 in rats with heart failure. Acta Histiochem 116: 1342-1349, 2014.

COOK JL, GRADY LK, COLVIN M, JOSEPH SM, BRISCO MA, WALS MN: Sex differences in the care of patients with advanced heart failure. Circ Cardiovasc Qual Outcomes 8: S56-S59, 2015.

CONSENSUS TRIAL STUDY GROUP: Effects of enalapril on mortality in severe congestive heart failure. Results of the Cooperative North Scandinavian Enalapril Survival Study (CONSENSUS). N Engl J Med 316: 1429-1435, 1987. 
ČERVENKA L, MELENOVSKÝ V, HUSKOVÁ Z, ŠKAROUPKOVÁ P, NISHIYAMA A, SADOWSKI J: Inhibition of soluble epoxide hydrolase counteracts the development of renal dysfunction and progression of congestive heart failure in Ren-2 transgenic hypertensive rats with aorto-caval fistula. Clin Exp Pharmacol Physiol 42: 795-807, 2015a.

ČERVENKA L, MELENOVSKÝ V, HUSKOVÁ Z, SPORKOVÁ A, BURGELOVÁ M, ŠKAROUPKOVÁ P, HWANG SH, HAMMOCK BD, IMIG JD, SADOWSKI J: Inhibition of soluble epoxide hydrolase does not improve the course of congestive heart failure and the development of renal dysfunction in rats with volume overload induced by aorto-caval fistula. Physiol Res 64: 857-873, 2015b.

ČERVENKA L, ŠKAROUPKOVÁ P, KOMPANOWSKA-JEZIERSKA E, SADOWSKI J: Sex-linked differences in the course of chronic kidney disease and congestive heart failure: a study in 5/6 nephrectomized Ren-2 transgenic hypertensive rats with volume overload induced using aorto-caval fistula. Clin Exp Pharmacol Physiol 43: 883-895, 2016.

DENT MR, TAPIIA PS, DHALLA NS: Gender differences in cardiac dysfunction and remodeling due to volume overload. J Card Fail 16: 439-449, 2010.

EISENBERG E, DI PALO KE, PINA IL: Sex differences in heart failure. Clin Cardiol 41: 211-216, 2018.

ELMARAKBY AA: Reno-protective mechanisms of epoxyeicosatrienoic acids in cardiovascular disease. Am J Physiol 302: R321-R330, 2012.

FERRARIO CM, MULLICK AE: Renin angiotensin aldosterone inhibition in the treatment of cardiovascular disease. Pharmacol Res 125: 51-71, 2017.

GARDNER JD, BROWER GL, JANICKI JS: Effects of dietary phytoestrogens on cardiac remodeling secondary to chronic volume overload in female rats. J Appl Physiol 99: 1378-1383, 2005.

HATT PY, RAKUSAN K, GASTINEAU P, LAPLACE M, CLUZEAUD F: Aorto-caval fistula in the rat. An experimental model of heart volume overloading. Basic Res Cardiol 75: 105-108, 1980.

HOŠKOVÁ L, MÁLEK I, KOPKAN L, KAUTZNER J: Pathophysiological mechanisms of calcineurin inhibitorinduced nephrotoxicity and arterial hypertension. Physiol Res 66: 167-180, 2017.

HOUSER SR, MARGULIES KB, MURPHY AM, SPINALE FG, FRANCIS GS, PRABHU SD, ROCKMAN HA, KASS DA, MOLKENTIN JD, SUSSMAN MA, KOCH WJ: Animals models of heart failure: a scientific statement from the American Heart Association. Circ Res 111: 131-150, 2012.

HRDLIČKA J, NECKÁŘ J, PAPOUŠEK F, HUSKOVÁ Z, KIKERLOVÁ S, VAŇOURKOVÁ Z, VERNEROVÁ Z, AKTA F, VAŠÍNOVÁ J, HAMMOCK BD, HWANG SH, IMIG JD, FALCK JR, ČERVENKA L, KOLÁŘ F: Epoxyeicosatrienoic acid-based therapy attenuate the progression of postischemic heart failure in normotensive Sprague-Dawley but not in hypertensive Ren-2 transgenic rats. Front Pharmacol 10: 159, 2019.

HSICH EM, PINA IL: Heart failure in women: a need for prospective data. J Am Coll Cardiol 54: 491-498, 2009.

HUSKOVÁ Z, KRAMER H, VAŇOURKOVÁ Z, THUMOVÁ M, MALÝ J, OPOČENSKÝ M, ŠKAROUPKOVÁ P, KOLSKÝ A, VERNEROVÁ Z, ČERVENKA L: Effects of dietary salt load and slat depletion on the course of hypertension and angiotensin II in male and female heterozygous Ren-2 transgenic rats. Kidney Blood Press Res 30: 45-55, 2007.

HUSKOVÁ Z, KOPKAN L, ČERVENKOVÁ L, DOLEŽELOVÁ Š, VAŇOURKOVÁ Z, ŠKAROUPKOVÁ P, NISHIYAMA A, KOMPANOWSKA-JEZIERSKA E, SADOWSKI J, KRAMER HJ, ČERVENKA L: Intrarenal alterations of the angiotensin-converting enzyme type 2/angiotensin 1-7 complex of the reninangiotensin system do not alter the course of malignant hypertension in Cyp1a1-Ren-2 transgenic rats. Clin Exp Pharmacol Physiol 43: 438-449, 2016.

IMIG JD: Prospectives for cytochrome P450 epoxygenase cardiovascular and renal therapeutics. Pharmacol Ter 2018 doi: 10.1016/j.pharmthera.2018.06.015.

ISHIZUKA T, ITO O, OMATA K, ITO S: Role of androgens in the renal production of 20-hydroxyeicosatrienoic acid in spontaneously hypertensive rats. Nihon Jinzo Gakai Shi 46: 685-692, 2004.

JAMIESON KL, ENDO T, DARWESH AM, SAMOKHVALOV V, SEUBERT JM: Cytochrome P450-derived eicosanoids and heart function. Pharmacol Ter 179: 47-83, 2017. 
KALA P, SEDLÁKOVÁ L, ŠKAROUPKOVÁ P, KOPKAN L, VAŇOURKOVÁ Z, TÁBORSKÝ M, NISHIYAMA A, HWANG SH, HAMMOCK BD, SADOWSKI J, MELENOVSKÝ V, IMIG JD, ČERVENKA L: Effect of angiotensin-converting enzyme blockade, alone or combined with blockade of soluble epoxide hydrolase, on the course of congestive heart failure and occurrence of renal dysfunction in Ren-2 transgenic hypertensive rats with aorto-caval fistula. Physiol Res 67: 401-415, 2018.

KASSI M, HANAWI B, TRACHTENBERG B: Recent advances in heart failure. Curr Opini Cardiol 33: 249-256, 2018.

KOBORI H, NANGAKU M, NAVAR LG, NISHIYAMA A: The intrarenal renin-angiotensin system: from physiology to the pathobiology of hypertension and kidney disease. Pharmacol Rev 59: 251-287, 2007.

KOPKAN L, KRAMER HJ, HUSKOVÁ Z, VAŇOURKOVÁ Z, ŠKAROUPKOVÁ P, THUMOVÁ M, ČERVENKA L: The role of intrarenal angiotensin II in the development of hypertension in Ren-2 transgenic rats. J Hypertens 23: 1531-1539, 2005.

KOPKAN L, ČERVENKA L: Renal interactions of renin-angiotensin system, nitric oxide and superoxide anion: implications in the pathophysiology of salt-sensitivity and hypertension. Physiol Res 58 Suppl 2: S55-S67, 2009.

KUJAL P, ČERTÍKOVÁ CHÁBOVÁ V, ŠKAROUPKOVÁ P, HUSKOVÁ Z, VERNEROVÁ Z, KRAMER HJ, WALKOWSKA A, KOMPANOVSKA-JEZIERSKA E, SADOWSKI J, KITADA K, NISHIYAMA A, HWANG SH, HAMMOCK BD, IMIG JD, ČERVENKA L: Inhibition of soluble epoxide hydrolase is renoprotective in 5/6 nephrectomized Ren-2 transgenic hypertensive rats. Clin Exp Pharmacol Physiol 41: 227-237, 2014. LEE MA, BOHM M, PAUL M, BADER M, GANTEN U, GANTEN D: Physiological characterization of the hypertensive transgenic rat TGR(mREN2)27. Am J Physiol 270: E919-E929, 1996.

LAM CS, MCENTEGART M, CLAGGET B, LIU J, SKALI H, LEWIS E, KOBER L, ROULEAU J, VELAZQUEZ E, CALIFF R, MCMURRAY JJ, PFEFFER M, SOLOMON S: Sex differences in clinical characteristics and outcomes after myocardial infarction: insight from the Valsartan Myocardial Infarction Trial (VALLIANT). Eur J Heart Fail 17: 301-312, 2015.

LEE MA, BOHM M, PAUL M, BADER M, GANTEN U, GANTEN D: Physiological characterization of the hypertensive transgenic rat TGR (mREN2)27. Am J Physiol 270: E919-E929, 1996.

LEWIS EF, LAMAS GA, O'MEARA E, GRANGER CB, DUNLAP ME, MCKELVIE RS, PROBSTFIELD JL, YOUNG JB, MICHELOSON EL, HALLING K, CARLSSON J, OLOFSSON B, MCMURRA JJ, YUSUF S, SWEDBERG K, PFEFFER MA: Characterization of health-related quality of life in heart failure patients with presereved versus low ejection fraction in CHARM. Eur J Heart Fail 9: 83-91, 2007.

LU H, MELÉNDEZ GC, LEVICK SP, JANICKI JS: Prevention of adverse cardiac remodeling to volume overload in female rats is the result of an estrogen-mediated altered mass cell phenotype. Am J Physiol 302: H811-H817, 2012.

MAGGIONI AP: Epidemiology of heart failure in Europe. Heart Fail Clin 11: 625-635, 2015.

MELENOVSKY V, SKAROUPKOVA P, BENES J, TORRESOVA V, KOPKAN L, CERVENKA L: The course of heart failure development and mortality in rats with volume overload due to aorto-caval fistula. Kidney Blood Press Res 35: 167-173, 2012.

MELENOVSKÝ V, CERVENKA L, VIKLICKY O, FRANEKOVA J, HAVLENOVA T, BEHOUNEK M, CHMEL M, PETRAK J: Kidney response to heart failure: proteomic analysis of cardiorenal syndrome. Kidney Blood Press Res 43: 1437-1450, 2018.

MILLER LR, MARKS C, BECKER JB, HURN PD, CHEN WJ, WOODRUFF T, MCCARTHY MM, SOHRABJI F, SCHIEBINGER L, WETHERINGTON CL, MAKRIS S, ARNOLD AP, EINSTEIN G, MILLER VM, SANDBERG K, MAIER S, CORNELISON TL, CLAYTON JA: Considering sex as a biological variable in preclinical research. FASEB J. 31: 29-34, 2017.

MULLINS JJ, PETERS J, GANTEN D: Fulminant hypertension in transgenic rat harboring the mouse Ren-2 gene. Nature 344: 541-544, 1990.

OSTADAL B, NETUKA I, MALY J, BESIK J, OSTADALOVA I: Gender differences in cardiac ischemic injury and protection - experimental aspects. Exp Biol Med (Maywood) 234: 1011-1019, 2009. 
PETRIE MC, DAWSON NF, MURDOCH DR, DAVIE AP, MCMCURRAY JJ: Failure of women's hearts. Circulation 99: 2334-2341, 1999.

PINHO-GOMES AC, RAHIMI K: Management of blood pressure in heart failure. Heart 105: 589-595, 2019.

PENDERGRASS KD, AVERILL DB, FERRARIO CM, DIZ DI, CHAPPELL MC: Differential expression of nuclear $\mathrm{AT}_{1}$ receptors and angiotensin II within the kidney of the male congenic mRen2 Lewis rat. Am J Physiol 290: F1497-F1506, 2006.

PLANTE E, LACHANCE D, BEAUDOIN J, CHAMPETIER S, ROUSSEL E, ARSENAULT M, COUET J: Comparative study of vasodilators in an animal model of chronic volume overload caused by severe aortic regurgitation. Circ Heart Fail 2: 25-32, 2009.

PONIKOWSKI P, VOORS AA, ANKER SD, BUENO H, CLELAND JG, COATS AJ, FALK V, GONZÁLEZJUANATEY JR, HARIOLA VP, JAKOWSKA EA, JESSUP M, LINDE C, NIHOANNOPOULOS P, PARISSIS JT, PIESKE B, RILEY JP, ROSANO GM, RUILOPE LM, RUSCHITZKA F, RUTTEN FH, VAN DER MEER P: 2016 ESC Guideliness for the diagnosis and treatment of acute and chronic heart failure: The Task Force of the diagnosis and treatment of acute and chronic heart failure of the European Society of Cardioloy (ESC) Developed with the special contribution of the Heart Failure Association (HFA) of the ESC. Eur Heart J 37: 2129-21200, 2016.

QIN J, KANDHI S, FROOGH G, JIANG H, LUO M, SUND D, HUANG A: Sexually dimorphic phenotype of arteriolar responsiveness to shear stress in soluble epoxide hydrolase-knockout mice. Am J Physiol 309: H1860-H1866, 2015.

QIN J, LE Y, FROOGH G, KANDHI S, JIANG S, LUO M, HUANG A: Sexually dimorphic adaptation of cardiac function: roles of epoxyeicosatrienoic acid and peroxisome proliferator-activated receptors. Physiol Rep 4: e12838, 2016.

REGITZ-ZAGROSEK V, KARAGIGAS G: Mechanistic pathways of sex differences in cardiovascular disease. Physiol Rev 97: 1-37, 2017.

ROCIC P, SCHWARTZMAN ML: 20-HETE in the regulation of vascular and cardiac function. Pharmacol Ter 192: 74-87, 2018.

ROMAN RJ, FAN F: 20-HETE: hypertension and beyond. Hypertension 72: 12-18, 2018.

RYAN TD, ROTHSTEIN EC, ABAN I, TALLAJ JA, HUSAIN A, LUCCHESI PA, DELL'ITALIA LJ: Left ventricular eccentric remodeling and matrix loss are mediated by bradykinin and precede cardiomyocyte elongation in rats with volume overload. J Am Soc Cardiol 49: 811-821, 2007.

SANTOS RAS, SAMPAIO WO, ALZAMORA AC, MOTTA-SANTOS D, ALENINA N, BADER M, CAPAGNOLESANTOS MJ: The ACE2/Angiotensin-(1-7)/Mas axis of the renin-angiotensin system: focus on angiotensin(1-7). Physiol Rev 98: 505-553, 2018.

SOLVD INVESTIGATORS: Effect of enalapril on mortality and the development of heart failure in asymptomatic patients with reduced left ventricular ejection fractions. N Engl J Med 327: 658-691, 1992.

SOUTH AM, SHALTOUT HA, WAHBURN LK, HENDRICKS AS, DIZ DI, CAHPPELL MC: Fetal programing and the angiotensin-(1-7) axis: a review of the experimental and clinical data. Clin Sci 133: 55-74, 2019.

SPORKOVA A, JÍCHOVÁ Š, HUSKOVÁ Z, KOPKAN L, NISHIYAMA A, HWANG SH, HAMMOCK BD, IMIG JD, KOMPANOWSKA-JEZIERSKA E, SADOWSKI J, KRAMER HJ, CERVENKA L: Different mechanism of acute versus long-term antihypertensive effects of soluble epoxide hydrolase inhibition: studies in Cyp1a1Ren-2 transgenic rats. Clin Exp Pharmacol Physiol 41: 1003-1013, 2014.

SPORKOVÁ A, HUSKOVÁ Z, ŠKAROUPKOVÁ P, REDDY NR, FALCK JR, SADOWSKI J, ČERVENKA L: Vasodilatory responses of renal interlobular arteries to epoxyeicosatrienoic acids analog are not enhanced in Ren-2 transgenic hypertensive rats: evidence against a role of direct vascular effects of epoxyeicosatrienoic acids in progression of experimental heart failure. Physiol Res 66: 29-39, 2017.

SULLIVAN JC, BHATIA K, YAMAMOTO T, ELMARKBY AA: Angiotensin (1-7) receptor antagonism equalizes angiotensin II-induced hypertension in male and female spontaneously hypertensive rats. Hypertension 56: 658-666, 2010. 
VANĚČKOVÁ I, HUSKOVÁ Z, VAŇOURKOVÁ Z, CERVENKA L: Castration has antihypertensive and organoprotective effects in male but not in female heterozygous Ren-2 rats. Kidney Blood Press Res 34: 46-52, 2011.

YANCY CW, JESSUP M, BOZKURT B, BUTLER J, CASEY DE, COLVIN MM, DRAZNER MH, FILIPATOS GS, FONAROW GC, GIVERTZ MM, HOLLENBERG SM, LINDEFELD J, MASOUDI FA, MCBRIDE PE, PETERSON PN, STEVENSON LW, WESTLAKE C: 2017 ACC/AHA/HFSA focused update of the 2013 ACCF/AHA Guideline for the management of heart failure. Circulation 136: e137-e161, 2017.

WESTERMAN S, WENGER NK: Women and heart disease, the underrecognized burden: sex differences, biases, and unmet clinical and research challenges. Clin Sci 130: 551-563, 2016. 